\title{
CLINICAL FEATURES OF THE HIV INFECTION COURSE AND THE DEPENDENCE OF CHANGES IN LABORATORY PARAMETERS ON THE CLINICAL STAGE AND ON THE CD4 LYMPHOCYTES LEVEL
}

DOI: $10.36740 /$ WLek202105126

\author{
Oksana M. Chemych, Mykola D. Chemych, Anna A. Olefir, Oleh B. Berest \\ SUMY STATE UNIVERSITY, SUMY, UKRAINE
}

\begin{abstract}
The aim: Is to determine the features of the HIV infection and changes in indicators of endogenous intoxication and immunoreactivity depending on the clinical stage and the level of CD4 lymphocytes.

Materials and methods: 72 HIV-patients were examined. Comparison group included 40 healthy blood donors. Clinical and laboratory examination was performed. Indicators of endogenous intoxication, nonspecific reactivity and inflammatory activity were calculated.

Results: Main opportunistic infections were: oropharyngeal candidiasis; tuberculosis of different localization, more often pulmonary tuberculosis; and brain toxoplasmosis ( $\mathrm{p}<0,05)$. Indices of endogenous intoxication and immunoreactivity are important objective criteria for diagnosis. In groups where the distribution of patients depended on the level of CD4 cells - HIV (CD4 $\geq 500)$ and HIV (CD4 $\leq 499-200)$, index changes were more pronounced than in the HIV I and HIV III groups. The most significant changes in indexes were in the HIV IV clinical group and the HIV (CD4 $\leq 199)$ group: endogenous intoxication indexes were increased by 1,2-7,5 and 1,9-13,7 times in both groups respectively. Non-specific reactivity indexes were decreased by 1,2-1,6 and 1,3-1,6 times, respectively; nuclear index (NI) in groups was 3 and 3,4 times higher $(p<0,05-0,001)$. Changes in indexes of inflammatory activity were observed $(p<0,05-0,001)$.

Conclusions: Main diagnosed opportunistic infections were: oropharyngeal candidiasis; tuberculosis of different localization; and brain toxoplasmosis ( $p<0,05)$. Indices of endogenous intoxication and immunoreactivity are important objective criteria for diagnosis. The most significant changes in indexes were in the HIV IV clinical group and the HIV (CD4 199$)$ group $(p<0,05-0,001)$.
\end{abstract}

KEY WORDS: HIV-infection, clinical course, indices, endogenous intoxication, immunoreactivity

Wiad Lek. 2021;74(5):1189-1195

\section{INTRODUCTION}

HIV is a threat to the entire global community. There are about $36,9[31,1-42,9]$ million people living with HIV worldwide. The disease rate is continuing to grow on almost every continent. According to WHO/UNAIDS, Ukraine continues to be a region with high HIV prevalence among other European and East Asian countries [1]. It also is remains on one of the first places among Eastern European countries by the disease growing rank. UNAIDS data shows that in 2019 there were 240,000 $(230,000-260,000)$ people living with HIV [2]. According to the Center for Public Health in Ukraine, at the beginning of 2020, there were 244,000 HIV-positive people. [3].

Opportunistic infections remain the leading cause of death for HIV-infected people. Taking in count the immunodeficiency in HIV-patients, those infections are more likely to be severe, with a tendency to generalize [4]. Changes in the clinical blood analysis and leukocyte formula are provoked by opportunistic infections and can be calculated by special formulas of indices of endogenous intoxication. Changes in the indices correlate with the level of intoxication, nonspecific reactivity and inflammatory changes in the body and can therefore be used in routine clinical practice $[5,6]$.

\section{THE AIM}

The aim is to determine the clinical features of the HIV infection and changes in indicators of endogenous intoxication and immunoreactivity depending on the clinical stage and the level of CD4 lymphocytes.

\section{MATERIALS AND METHODS}

72 HIV were examined. All treatment and diagnostic procedures were performed with the informed consent of the patients. A clinical and laboratory examination was performed according to the protocol. Clinical blood test (CobasMicros); biochemical blood test performed at the hospital laboratory (SOBASEMira); PCR / ELISA at the Sinevo commercial laboratory; radiological and magnetic resonance examination were performed; confirmation of the HIV-diagnosis was performed by the PCR / ELISA method (quality method of RNA detection) at the Sumy "Regional Clinical Medical Center of Socially Dangerous Diseases". We calculated integrative indices of endogenous intoxication and immunoreactivity: leucocyte intoxication index (LII), hematological index of intoxication (HII), 
index of leucocytes shift (ISL), Krebs index (KI), immunoreactivity index (IR), lymphocyte-granulocyte index (ILG), neutrophil-lymphocyte ratio (NLR), lymphocyte-monocyte ratio (LMR), neutrophil reactive response (NRR), index of leukocyte and ESR ratio (ILESR), lymphocyte index $\left(\mathrm{I}_{\text {lymph }}\right)$, eosinophils-lymphocyte ratio (ELR), index of allergization (IA), nuclear index (NI), index of intoxication severity (IIS) $[6,7]$.

Indicators of endogenous intoxication and immunoreactivity were calculated in patients depending on the clinical stage and depending on the level of CD-4 cells. Patients were divided into three groups in accordance with clinical stage of HIV: HIV I; HIV III; HIV IV (6; 10; 56 people respectively), patients with clinical stage II were not among the hospitalized. Depending on the level of CD4, patients were divided into three groups: $\mathrm{HIV}(\mathrm{CD} 4 \geq 500) /$

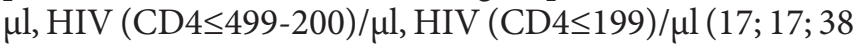
people respectively).

Comparison group included 40 healthy blood donors from the Sumy regional center of blood transfusions, aged $(37,95 \pm 1,72)$ years. The group had equally 20 men and women.

The statistical processing was performed in the Microsoft Office Excel 2010 and IBM SPSS Statistic 23 computer software. Data were checked for group distribution normality using the Shapiro-Wilk statistics. In the general group of patients we used parametric methods because the data obtained conform the normal distribution Student's t-test was used to analyze the quantitative data. When dividing patients into groups, depending on the stage of HIV-infection we used non-parametric methods because the data obtained did not conform the normal distribution - Mann-Whitney U-test was used to analyze the quantitative data. To determine the significance of the differences between the frequency indices in the general group when comparing the qualitative characteristics, they were performed by constructing conjunction tables using the Pearson $\chi 2$ criterion. All the used tests were two-sided, $p<0.05$ values were considered statistically significant. The results of the study in the text and tables are presented in the form of a mean value, standard deviation or median, interquartile range (25th to 75 th percentiles).

Present information about study design, applied methods and search of conflicts of interest when conceptualizing the data and before writing a final text of original article. Keeping a non-interventional nature of the presented work the appropriate anonymity and personal data processing were ethically verified according to the local hospital and the All-Ukrainian rules and orders. Basically, he Declaration of Helsinki (6th, rev., 2008, Seol) and the Universal Declaration on Bioethics and Human Rights (2006) were a key documentation considering ethical decision making and conceptualization for the article's scientific content.

\section{RESULTS}

Medical records of 72 patients, aged $(39,02 \pm 0,96)$ years, were examined and processed. Male patients prevailed -
$69,44 \%$ ( $p<0,001)$. More often, HIV-infected had the fourth clinical stage (56 people; $77,78 \%$; $p<0,001$ ); third stage was diagnosed 5,6 times less than the fourth $(10 ; 13,89 \%)$, and the first stage $-9,3$ times less $(6 ; 8,33 \%)$; there were no patients with the second stage.

During hospitalization, almost all patients had complaints of weakness $(95,83 \%)(p<0,01)$. Less common complaints were: headache $(29,17 \%)$, dizziness $(26,39 \%)$, decreased appetite $(25,0 \%)(\mathrm{p}<0,05)$. Weight loss $(22,22 \%)$, nausea/vomiting $(20,83 \%)$, cough $(18,06 \%)$, sore throat $(16,67 \%)$, impaired vision $(12,5 \%)$. In single cases we observed: abdominal pain $(9,72 \%)$, heartache $(8,33 \%)$, memory impairment $(8,33 \%)$, irritability $(8,33 \%)$, seizures $(6,94 \%)$, shortness of breath $(5,56 \%)$, heartburn $(4,17 \%)$, arthralgia $(4,17 \%)$, jaundice $(4,17 \%)$, peripheral edema $(2,78 \%)$, rash $(2,78 \%)$ and muscle pain $(1,39 \%)$.

During objective examination, the most common symptoms were lymphadenopathy $(91,67 \%)$ and hepatomegaly $(81,94 \%) \mathrm{p}<0,05$, less frequent symptoms were splenomegaly $(4,17 \%)$. Liver edge expanded about $(3,69 \pm 0,42)$ $\mathrm{cm}$ below costal margin, the enlargement rate depended on accompanying pathology and was more expressed in patients with HIV infection combined with viral hepatitis. Patients experienced an increase in body temperature up to $(37,69 \pm 0,42){ }^{\circ} \mathrm{C}$.

Our findings demonstrate that such opportunistic infections as oropharyngeal candidiasis $(62,50 \%)$, tuberculosis of various localizations $(36,11 \%)$ and brain toxoplasmosis $(23,61 \%)(p<0,05)$ were more frequent than the others.

Seborrheic dermatitis was diagnosed 4,5 times less often $(13,89 \%$; $p<0,01)$ compare to the oropharyngeal candidiasis; pneumocystis pneumonia was found in 3,7 times less cases $(9,72 \% ; p<0,001)$ than tuberculosis. In rare cases of HIV infection, angular cheilitis (2,78\%), Epstein-Barr virus encephalitis $(2,78 \%)$, mucosal papillomatosis of oropharyngeal mucous membrane $(2,78 \%)$, chronic generalized cytomegalovirus infection (2,78\%), herpes zoster $(2,78 \%)$, onychomycosis $(2,78 \%)$, progressive multifocal leukoencephalopathy $(2,78 \%)$ were diagnosed.

Patients with tuberculous lesions were most often diagnosed for the first time with pulmonary tuberculosis - in $57,70 \%$ of cases $(p<0,05)$, what is 2,5 times more often compared to the occurrence of tuberculous meningitis $(23,10 \%)$. In isolated cases, there were: relapse tuberculosis $(7,69 \%)$, disseminated pulmonary tuberculosis $(3,85 \%)$, tuberculous meningoencephalitis $(3,85 \%)$, rifampicin-resistant tuberculosis $(3,85 \%)$.

Among other pathologies viral hepatitis $(62,50 \%)$ and metabolic cardiomyopathy $(56,94 \%)$ were the most common, and retinal angiopathy of both eyes $(25,0 \%)$, and encephalopathy $(11,11 \%) \mathrm{p}<0,001$ were less common. In isolated cases, the examination also revealed: leukemia $(4,17 \%)$, chronic pancreatitis $(4,17 \%)$, intestinal dysbiosis $(1,39 \%)$, diabetes mellitus type $1(1,39 \%) \mathrm{p}<0,001$.

Among the causes of chronic liver damage hepatitis $\mathrm{C}$ virus prevailed: it was detected in 50,0\% of HIV-infected patients $(\mathrm{p}<0,01)$. Less common was hepatitis $B$ virus - in $9,72 \%$; and in $2,78 \%$ of cases mixed hepatitis $B$ and $D$ virus 
Table I. Total blood count in patients with HIV infection of different clinical stages $(\mathrm{M} \pm \mathrm{m})$

\begin{tabular}{|c|c|c|c|c|}
\hline \multirow[b]{2}{*}{ Indicator } & \multicolumn{4}{|c|}{ Group } \\
\hline & $\begin{array}{c}\text { Comparison } \\
(n=40)\end{array}$ & $\begin{array}{l}\text { HIV I } \\
(n=6)\end{array}$ & $\begin{array}{l}\text { HIV III } \\
(n=10)\end{array}$ & $\begin{array}{l}\text { HIV IV } \\
(n=56)\end{array}$ \\
\hline Hemoglobin, g/l & $128,67 \pm 1,96$ & $132 \pm 5,73$ & $124,80 \pm 10,91$ & $117,66 \pm 3,57^{*, a}$ \\
\hline Erythrocytes, $\times 10^{12} / \mathrm{I}$ & $4,09 \pm 0,05$ & $4,42 \pm 0,22$ & $4,11 \pm 0,39$ & $3,86 \pm 0,12$ \\
\hline ESR, мм/год & $4,1 \pm 0,49$ & $13,50 \pm 5,93^{*}$ & $24,40 \pm 7,06 *$ & $31,61 \pm 2,86^{*, a}$ \\
\hline Leukocytes, $\times 10^{9} / /$ & $6,01 \pm 0,22$ & $9,19 \pm 3,98$ & $5,26 \pm 0,51$ & $4,45 \pm 0,39^{*}$ \\
\hline Platelets, $\times 10^{9} / /$ & $201,60 \pm 7,7$ & $181,0 \pm 9,86$ & $169,4 \pm 7,85 *$ & $174,45 \pm 10,87^{*}$ \\
\hline
\end{tabular}

Note.Significant difference in indicators ( $p<0,05-0,001$, Student's t-test used): ${ }^{*}$ - group of healthy individuals; ${ }^{a}$ - HIV I; ${ }^{b}-$ HIV III; ${ }^{c}$ - HIV IV.

Table II. Total blood count in patients with HIV infection with different levels of CD4 (M $\pm m)$

\begin{tabular}{|c|c|c|c|c|}
\hline \multirow[b]{2}{*}{ Indicator } & \multicolumn{4}{|c|}{ Group } \\
\hline & $\begin{array}{l}\text { Comparison } \\
(n=40)\end{array}$ & $\begin{array}{c}\text { HIV } \\
(C D 4 \geq 500) \\
(n=17)\end{array}$ & $\begin{array}{c}\text { HIII } \\
(\text { CD4 } \leq 499-200) \\
(n=17)\end{array}$ & $\begin{array}{c}\text { HIV } \\
(C D 4 \leq 199) \\
(n=38)\end{array}$ \\
\hline Hemoglobin, g/l & $128,67 \pm 1,96$ & $137,76 \pm 16,29$ & $116,71 \pm 9,38$ & $115,87 \pm 3,68^{*}$ \\
\hline Erythrocytes, $\times 10^{12} / /$ & $4,09 \pm 0,05$ & $4,42 \pm 0,27$ & $3,96 \pm 0,32$ & $3,86 \pm 0,14$ \\
\hline ESR, мм/год & $4,1 \pm 0,49$ & $10,12 \pm 2,13^{*, b, c}$ & $28,82 \pm 5,36^{*, a}$ & $30,92 \pm 3,41^{*, a}$ \\
\hline Leukocytes, $\times 10^{9} / \mathrm{I}$ & $6,01 \pm 0,22$ & $8,49 \pm 1,51$ & $5,93 \pm 0,97$ & $4,93 \pm 0,37^{*, a}$ \\
\hline Platelets, $\times 10^{9} / /$ & $201,60 \pm 7,7$ & $189,94 \pm 9,76$ & $170,71 \pm 9,48 *$ & $164,24 \pm 11,30^{*}$ \\
\hline
\end{tabular}

Note.Significant difference in indicators ( $p<0,05-0,001$, Student's t-test used): * - group of healthy individuals; a HIV (CD4 $\geq 500) ;{ }^{b}$ - HIV group

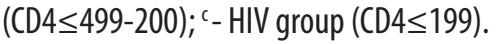

infection was found. Mixed hepatitis B and C infection was observed in $4,18 \%$ of examined HIV patients with liver disease.

The most common complications were anemia $-86,11 \%$ $(\mathrm{p}<0,001)$ and leukopenia, though it was 3,6 less times diagnosed $(23,61 \%)$. Also following pathologies were found: encephalopathy - in $11,11 \%$ of patients, psychomotor agitation $-8,33 \%$, liver cirrhosis $-5,56 \%$, brain infarction $-4,17 \%$, ascites $-1,40 \%$. Cirrhosis of the liver and ascites were diagnosed in HIV-infected patients with chronic viral hepatitis.

In order to evaluate the results of clinical blood test of HIV-infected patients, they were compared to the blood results of a comparison group that did not differ in age and sex structure. The number of erythrocytes in patients with HIV infection did not differ from those of the comparison group and were within normal ranges. Erythrocytes sedimentation rate in HIV-patients was higher in all groups. Whereas hemoglobin levels platelet and leukocytes count tended to decrease, significantly lower rates were in groups HIV IV and HIV (CD4 $\leq 199)$ compared with healthy individuals ( $\mathrm{p}<0,05-0,001)$ (Table I, II).

Intoxication indexes and immunoreactivity index were calculated in HIV- infected patients. Patients were divided into three groups, with the respect of the clinical stage of HIV: HIV I; HIV III; HIV IV, patients with clinical stage II were not among the hospitalized. Patients in the HIV I group had a 3,6-time increase of NRR, compare to the healthy group $(\mathrm{p}=0,01)$ and 6,3 -time increase compare to the patients with HIV-III $(\mathrm{p}=0,009)$. Others indexes values in HIV I group did not have a significant difference with the comparison group values (Table III).

In HIV III group, endogenous intoxication index such as IIS was 3,7 times higher compare to relatively healthy individuals $(\mathrm{p}<0,001)$, but compare to the HIV I and HIV IV groups there was no significant difference in IIS values. NRR in the HIV III group was 1,8-6,3 times lower than in healthy, HIV I and HIV IV groups ( $p=0,05 ; p=0,009$; $\mathrm{p}<0,001)$. LII, HII and ISL did not have significant differences in values between groups. Non - specific reactivity indexes (IR, NLR, LMR, I $_{\text {lymph }}$, ELR, IA, NI,) were not significantly different from the group of healthy individuals. Among other indexes, the ILESR values were 6,3 times higher if compared to healthy group $(\mathrm{p}<0,001)$, KI and ILG did not change (Table III).

In the HIV IV group, intoxication indexes: LII, ISL, HII, IIS, NRR were increased by $1,2-7,5$ times compare to the group of healthy individuals ( $\mathrm{p}=0,040 ; \mathrm{p}=0,091 ; \mathrm{p}=0,001$; $\mathrm{p}<0,001 ; \mathrm{p}<0,001)$. Non-specific reactivity indexes: IR, LMR, $I_{\text {lymph }}$, IA were $1,2-1,6$ times lower compare to the healthy ( $p=0,008 ; p=0,008 ; p=0,039 ; p=0,035)$; NI was 3 times higher than in healthy individuals and was 2,5 times higher than in patients of HIV III group $(p<0,001)$, NLR and ELR did not significantly differ from the comparison group. Indexes of inflammatory activity also changed in patients with HIV IV: ILG was 1,2 times lower $(p=0,012)$, and ILESR was 6,5 times higher compare to healthy individuals $(\mathrm{p}<0,001)$, KI had no significant changes (Table III).

In the immunological study, the level of CD4 lymphocytes was $(269,28 \pm 37,39)$ cells/ $\mu$ l. Depending on the level of CD4, 
Table III. Integrative leucocyte intoxication index (LII) and immunoreactivity index (IR) in patients with HIV infection of different clinical stages (Median, interquartile range)

\begin{tabular}{|c|c|c|c|c|}
\hline \multirow[b]{2}{*}{ Indicator, (Un) } & \multicolumn{4}{|c|}{ Group } \\
\hline & $\begin{array}{c}\text { Comparison } \\
(n=40)\end{array}$ & $\begin{array}{l}\text { HIV I } \\
(n=6)\end{array}$ & $\begin{array}{l}\text { HIV III } \\
(n=10)\end{array}$ & $\begin{array}{l}\text { HIV IV } \\
(n=56)\end{array}$ \\
\hline \multicolumn{5}{|c|}{ Intoxication indexes } \\
\hline LII & $0,56(0,30-0,93)$ & $0,56(0,16-4,94)$ & $0,44(0,33-1,60)$ & $0,92(0,35-2,40)^{*}$ \\
\hline ISL & $1,49(1,14-1,94)$ & $1,96(0,94-6,50)$ & $1,47(0,98-2,23)$ & $1,74(1,18-4,10)^{*}$ \\
\hline HII & $0,53(0,29-0,84)$ & $0,51(0,22-17,20)$ & $0,46(0,34-2,53)$ & $1,04(0,46-4,64)^{*}$ \\
\hline IIS & $0,11(0,04-0,24)$ & $0,33(0,05-21,21)$ & $0,41(0,30-1,26)^{*}$ & $0,83(0,20-5,96)^{*}$ \\
\hline NRR & $8,91(3,89-15,71)$ & $31,98(10,30-101,75)^{*, b}$ & $5,07(0,001-11,94)^{*, a, c}$ & $26,79(11,04-86,98)^{*, b}$ \\
\hline \multicolumn{5}{|c|}{ Non-specific reactivity indexes } \\
\hline IR & $4,46(2,90-6,65)$ & $5,81(2,40-8,44)$ & $3,12(2,12-7,62)$ & $2,80(1,68-5,25)^{*}$ \\
\hline NLR & $6,32(5,33-11,27)$ & $9,00(5,02-32,88)$ & $6,68(5,81-10,54)$ & $7,10(4,92-12,48)$ \\
\hline LMR & $4,06(2,60-6,22)$ & $5,46(2,10-7,06)$ & $2,90(1,86-7,17)$ & $2,64(1,50-4,88)^{*}$ \\
\hline $\mathrm{I}_{\text {lymph }}$ & $0,55(0,42-0,71)$ & $0,47(0,10-1,0)$ & $0,51(0,37-0,92)$ & $0,47(0,18-0,68)^{*}$ \\
\hline ELR & $0,06(0,03-0,11)$ & $0,09(0,04-0,30)$ & $0,04(0,001-0,17)$ & $0,05(0,001-0,18)$ \\
\hline IA & $0,93(0,75-1,46)$ & $1,20(0,42-2,17)$ & $1,11(0,55-1,47)$ & $0,74(0,36-1,23)^{*}$ \\
\hline $\mathrm{NI}$ & $0,05(0,03-0,09)$ & $0,10(0,05-0,68)$ & $\begin{array}{c}0,06(0,03-0,09) \\
(c \mathrm{p}<0,001)\end{array}$ & $0,15(0,10-0,40)^{*, b}$ \\
\hline \multicolumn{5}{|c|}{ Indexes of activity of inflammation } \\
\hline $\mathrm{KI}$ & $1,83(1,42-2,37)$ & $2,14(1,05-9,60)$ & $1,96(1,09-3,05)$ & $2,15(1,48-5,68)$ \\
\hline ILG & $4,71(3,51-5,87)$ & $3,71(0,97-7,92)$ & $4,11(3,07-7,58)$ & $3,96(1,53-5,32)^{*}$ \\
\hline ILESR & $0,89(0,70-1,53)$ & $1,47(0,82-5,58)$ & $5,60(2,37-10,33)^{*}$ & $5,76(2,38-8,54)^{*}$ \\
\hline
\end{tabular}

Note. Significant difference in indexes ( $p<0,05-0,001$, according to the Mann-Whitney criterion) compared to: * - group of healthy individuals; a - HIV I; b - HIV III; c - HIV IV.

patients were divided into three groups: $\mathrm{HIV}(\mathrm{CD} 4 \geq 500) / \mu \mathrm{l}$,

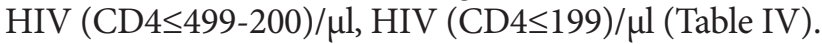

In the HIV (CD4 $\geq 500)$ group, IIS was increased by 3,4 times compare to the healthy group $(p=0,001)$. NI and ILESR indexes were 1,8 times $(p=0,013)$ and 2,5 times $(p=0,004)$ higher respectively, compare to healthy subjects. Other indexes did not have significant differences from the comparison group (Table IV).

In the HIV (CD4 $\leq 499-200)$ group, intoxication indexes such as ISL, HII, IIS and NRR were 1,2-3 times higher $(\mathrm{p}=0,045 ; \mathrm{p}=0,048 ; \mathrm{p}<0,001 ; \mathrm{p}<0,001)$ than in healthy individuals. The LII did not change. NRR was 2,8 times higher $(p=0,006)$ than in the HIV $(C D 4 \geq 500)$ group. Indexes of non-specific reactivity, such as IR, LMR, $\mathrm{I}_{\text {lymph }}$, in patients of HIV (CD4 4499-200) group were 1,1-2 times lower than those of healthy people $(p=0,024 ; p=0,033 ; p=0,045)$, and NI was 2,4 times higher $(\mathrm{p}=0,004)$. NLR, ELR, IA had no significant difference in their values from the comparison group. In patients with HIV (CD4 $\leq 499-200)$, indexes of inflammatory activity were as follows: KI and ILESR were $1,1-6,7$ times higher $(p=0,043 ; p<0,001)$ and ILG was 1,2 times lower $(p=0,023)$ than those of the comparison group (Table IV).

In patients with HIV (CD $4 \leq 199)$, IIS, NRR, LMR, NI, and ILG values differed significantly from the HIV (CD4 $\geq 500)$ group (Table IV).
Intoxication indexes such as LII, HII, IIS, NRR were 1,913,7 times higher among patients with HIV (CD4 $\leq 199)$ $(\mathrm{p}=0,027 ; \mathrm{p}=0,001 ; \mathrm{p}<0,001 ; \mathrm{p}<0,001)$, ISL had no distinct changes in values compare to healthy people. Indexes of non-specific reactivity: IR, LMR, $\mathrm{I}_{\text {lymph}}$, IA - decreased by $1,3-1,6$ times $(p=0,009 ; p=0,006 ; p=0,021 ; p=0,043)$, and IA increased by 3,4 times $(\mathrm{p}<0,001)$, NLR and ELR did not change. Indexes of inflammatory activity: ILG was 1,3 times lower $(p=0,005)$, and ILESR was 6,6 times higher $(\mathrm{p}<0,001)$ compare to healthy individuals, KI was not significantly different from the comparison group (Table IV).

\section{DISCUSSION}

Since HIV infection affects mostly working age population. Low detection rate of HIV-infection at first stages we associate with non-specific clinical features of this period [8].

Our findings demonstrate that such opportunistic infections as oropharyngeal candidiasis, tuberculosis of various localizations and brain toxoplasmosis were more frequent than the others $(\mathrm{p}<0,05)$. The frequency of oropharyngeal candidiasis has increased significantly in recent years. It is caused by the uncontrolled use of antibiotics, which have broad spectrum of action. According to studies by other authors, oropharyngeal candidiasis is found in $44 \%$ 
Table IV. Integrative indexes of endogenous intoxication and immunoreactivity in patients with HIV infection with different levels of CD4 (Median, interquartile range)

\begin{tabular}{|c|c|c|c|c|}
\hline \multirow[b]{2}{*}{ Indicator, (Un) } & \multicolumn{4}{|c|}{ Group } \\
\hline & $\begin{array}{c}\text { Comparison } \\
(n=40)\end{array}$ & $\begin{array}{c}\text { HIV (CD4 } \geq 500) \\
(n=17)\end{array}$ & $\begin{array}{c}\text { HIV (CD4 } \leq 499-200) \\
(n=17)\end{array}$ & $\begin{array}{c}\text { HIV (CD4 } \leq 199) \\
(n=38)\end{array}$ \\
\hline \multicolumn{5}{|c|}{ Intoxication indexes } \\
\hline LII & $0,56(0,30-0,93)$ & $0,45(0,30-1,29)$ & $0,79(0,27-2,06)$ & $1,07(0,31-5,77)^{*}$ \\
\hline ISL & $1,49(1,14-1,94)$ & $1,22(0,96-1,87)$ & $1,80(1,41-3,17)^{*}$ & $2,03(1,20-5,87)$ \\
\hline HII & $0,53(0,29-0,84)$ & $0,48(0,32-1,23)$ & $0,88(0,34-4,36)^{*}$ & $1,99(0,44-10,80)^{*}$ \\
\hline IIS & $0,11(0,04-0,24)$ & $0,37(0,13-0,73)^{*, c}$ & $0,33(0,19-3,81)^{*}$ & $1,51(0,29-7,87)^{*, a}$ \\
\hline NRR & $8,91(3,89-15,71)$ & $8,67(3,58-17,72)^{\mathrm{b}, \mathrm{c}}$ & $24,24(15,62-53,82)^{*, a}$ & $40,68(13,42-112,94)^{*, a}$ \\
\hline \multicolumn{5}{|c|}{ Non-specific reactivity indexes } \\
\hline IR & $4,46(2,90-6,65)$ & $4,89(2,77-7,29)$ & $2,25(1,59-5,41)^{*}$ & $2,74(1,60-5,25)^{*}$ \\
\hline NLR & $6,32(5,33-11,27)$ & $6,57(5,33-12,63)$ & $7,00(5,17-11,02)$ & $7,84(3,76-14,63)$ \\
\hline LMR & $4,06(2,60-6,22)$ & $4,78(2,53-7,07)^{c}$ & $2,00(1,43-4,95)^{*}$ & $2,57(1,52-4,90)^{*, a}$ \\
\hline $\mathrm{I}_{\text {lymph }}$ & $0,55(0,42-0,71)$ & $0,68(0,39-0,92)$ & $0,48(0,20-0,58)^{*}$ & $0,41(0,11-0,65)^{*}$ \\
\hline ELR & $0,06(0,03-0,11)$ & $0,06(0,02-0,10)$ & $0,08(0,001-0,19)$ & $0,04(0,001-0,19)$ \\
\hline IA & $0,93(0,75-1,46)$ & $1,03(0,56-1,50)$ & $0,65(0,44-1,27)$ & $0,71(0,27-1,38)^{*}$ \\
\hline $\mathrm{NI}$ & $0,05(0,03-0,09)$ & $0,09(0,06-0,11)^{*, c}$ & $0,12(0,05-0,22)^{*}$ & $0,17(0,10-0,44)^{*, a}$ \\
\hline \multicolumn{5}{|c|}{ Indexes of activity of inflammation } \\
\hline $\mathrm{KI}$ & $1,83(1,42-2,37)$ & $1,47(1,08-2,57)$ & $2,10(1,74-5,00)^{*}$ & $2,13(1,31-7,23)$ \\
\hline ILG & $4,71(3,51-5,87)$ & $5,63(3,28-7,61)^{c}$ & $3,80(1,71-4,71)^{*}$ & $3,60(0,98-5,10)^{*, a}$ \\
\hline ILESR & $0,89(0,70-1,53)$ & $2,24(0,93-7,83)^{*}$ & $5,92(2,22-8,85)^{*}$ & $5,89(2,88-9,10)^{*}$ \\
\hline
\end{tabular}

Note. Significant difference in indexes ( $p<0,05-0,001$, according to the Mann-Whitney criterion) compared to: ${ }^{*}$ - group of healthy individuals; ${ }^{a}$ HIV (CD4 $\left.\geq 500\right) ;{ }^{b}$ - HIV group (CD4 $\left.\leq 499-200\right) ;{ }^{c}-$ HIV group (CD4 $\left.\leq 199\right)$.

of patients with HIV infection and in $60-90 \%$ of patients with AIDS [9]. As for toxoplasmosis, diagnosing patients with toxoplasma encephalitis only indicates late HIV finding and start of antiretroviral therapy. Thus, in $56,3 \%$ of patients toxoplasmosis is diagnosed on the background of deep immunosuppression, and in $21,5 \%$ of cases it is fatal. The probability of lethal cases increases with the decrease in number of CD4-lymphocytes (less than 50 cells $/ \mathrm{ml}$ ), the absence of antiretroviral therapy and the presence of co-infection of the central nervous system, including tuberculosis $[10,11]$. Among all diseases indicative for AIDS, tuberculosis remains the the most common cause of death in Ukraine and in many other countries. And tuberculosis, unlike other opportunistic infections, can develop in patients with different CD4 lymphocyte count and at any stage of AIDS [11].

HIV is capable of affecting and destroying the cells of the nervous system, that have CD4 receptors on their membranes, such neurological complications as encephalopathy and progressive multifocal leukoencephalopathy might be a result of direct action of HIV [12].

The appearance of both HIV and viral hepatitis in patients can be explained by the same transmission route. A lower percentage of hepatitis $B$ is associated with effective specific prevention measures. On the background of HIV, viral hepatitis more often becomes chronic and twice as faster develops cirrhosis of liver [13, 14].
Because in the majority of patients accompanying somatic diseases were observed, we can assume that the increase in band neutrophils and eosinophils is the result of reactive states. The number of lymphocytes on the contrary was reduced $(\mathrm{p}<0,05)$, indicating primary or secondary immunodeficiency and deep decompensation of HIV infection [15]. HIV infection is associated with many hematopoietic disorders, what affects both lymphoid and myeloid hematopoiesis, therefore following changes of peripheral blood can be found: neutropenia, thrombocytopenia, and anemia [5].

The decline in lymphocyte count and high number of rods neutrophils in HIV patients led to an increase of integrative endogenous intoxication indexes: LII, ESL, HII, IIS, NRR. Those indexes indicate endogenous intoxication and the presence of an inflammatory process due to the opportunistic infections. Immune reactivity is impaired as a result of organism auto-intoxication due to the destruction of its own cells and the presence of exogenous factors, including persistence of viruses or bacterial endo- and exotoxins. Non-specific reactivity indexes (IR, LMR, $\mathrm{I}_{\text {lymph }}$ IA) were decreased, whereas NI was elevated due to the shift in the white blood cell count toward neutrophils and the prevalence of non-segmented forms over segmented, what stands for the presence of inflammatory reaction $[6,7]$. Neutrophil's ability to eliminate antigens was impaired due to the increased number 
of immature forms. The indexes reflect the ratio between neutrophil and lymphocyte percentage counts, indicating whereas humoral or cellular immunity is involved. In examined HIV infected patients, humoral immune response prevailed. Specifically, an increase in ILESR indicates about the presence of endogenous intoxication due to the autoimmune process [16].

\section{CONCLUSIONS}

1 . Young men of working age $(\mathrm{p}<0,001)$ were predominant among HIV-infected persons. More than $70 \%$ of patients were diagnosed with HIV for the first time on the fourth clinical stage.

2. The main complaints during hospitalization were: weakness $(95,83 \%)$, headache $(29,17 \%)$, dizziness $(26,39 \%)$, decreased appetite $(25,0 \%)(\mathrm{p}<0,05)$. During objective examination, the most common symptoms were lymphadenopathy $(91,67 \%)$, hepatomegaly $(81,94 \%)$, body temperature increase $(47,2 \%)(\mathrm{p}<0,05)$.

3. Main opportunistic infections were: oropharyngeal candidiasis (62,5\%); tuberculosis of different localization $(36,10 \%)$, more often pulmonary tuberculosis $(57,7 \%)$; and brain toxoplasmosis $(23,61 \%)(\mathrm{p}<0,05)$.

4. Indices of endogenous intoxication and immunoreactivity are important objective criteria for diagnosis. In groups where the distribution of patients depended on the level of CD4 cells - HIV (CD4 $\geq 500)$ and HIV (CD4 $\leq 499-200)$, index changes were more pronounced than in the HIV I and HIV III groups.

5. The most significant changes in indexes were in the HIV IV clinical group and the HIV (CD4 199$)$ group: endogenous intoxication indexes (LII, ISL, HII, IIS, NRR) were increased by 1,2-7,5 and 1,9-13,7 times in both groups respectively. Non-specific reactivity indexes (IR, LMR, $\mathrm{I}_{\text {lymph }}$, IA) were decreased by 1,21,6 and 1,3-1,6 times, respectively; NI in groups was 3 and 3,4 times higher $(p<0,05-0,001)$. Changes in indexes of inflammatory activity were observed: ILG was decreased by 1,2 and 1,3 times, respectively, and ILESR was increased by 6,5 and 6,6 times, respectively $(\mathrm{p}<0,05-0,001)$.

\section{REFERENCES}

1. UNAIDS report. Geneva. 2018. https://www.unaids.org/en/ resources/presscentre/pressreleaseandstatementarchive/2018/ november/20181122_WADreport_PR.

2. UNAIDS. Country factsheets UKRAINE. 2018. https://www.unaids.org/ $\mathrm{ru} /$ regionscountries/countries/ukraine .

3. Site of Center for Public Health of Ukraine. https://phc.org.ua/kontrolzakhvoryuvan/vilsnid/statistika-z-vilsnidu.

4. HIV infection in Ukraine. Newsletter. 2019; 50:35-37. https://phc.org. ua/sites/default/files/users/user90/HIV_in_UA_50_2019.pdf.

5. Rodionova I. 0., Crypnichenko S. V, Skrypnichenko T. S. Hemorahichnyi syndrom u VIL infikovanykh patsiientiv [Hemorrhagic syndrome in HIV infected patients]. Naukovyi visnyk Natsionalnoho medychnoho universytetu imeni 0. 0. Bohomoltsia [National Scientific Bulletin 00 Bogomolets Medical University]. 2013; 4: 93-96. (in Ukrainian).
6. Chemych 0.M., MorozL.V., Berest 0. B. et al. Rozrakhuvannia pokaznykiv endohennoi intoksykatsii ta imunoreaktyvnosti u khvorykh na hostri kyshkovi infektsii z vykorystanniam stvorennoho android-dodatku [Calculation of endogenous intoxication and immunoreactivity indicators in patients with acute intestinal infection using created android-application]. Zhurnal klinichnykh ta eksperymentalnykh medychnykh doslidzhen. [Journal of Clinical and Experimental Medical Research]. 2016; 4(4): 572-582. (in Ukrainian).

7. Chemych M. D., Sosnovenko D. S., Chemych 0. M. et al. Hematological changes of endogenic intoxication, non-specific reactivity and inflammation activity indices in hiv-infected patients. Wiadomosci lekarskie. 2020; 73(5): 983-987.

8. Site of World health Organization. https://www.who.int/home.

9. Vrincanu N.A. Kandydoz. Problemy ta perspektyvy antyfunhalnoi terapii (chastyna I) [Candidiasis. Problems and Prospects of Antifungal Therapy (Part I)]. Farmakolohiia ta likarska toksykolohiia. [Pharmacology and drug toxicology]. 2016; 6: 3-11. (in Ukrainian).

10. Shostakovych-Koretska L. R., Lytvyn K. Y., Volikova 0.0. et al. Kharakterystyka tserebralnoho toksoplazmozu u patsiientiv z vil: retrospektyvnyi analiz 135 vypadkiv u dnipropetrovskomu rehioni. [Characteristics of cerebral toxoplasmosis in HIV-patients: a retrospective analysis of 135 cases in the Dnepropetrov region]. Visnyk naukovykh doslidzhen - Journal of Scientific papers research. 2017; 4. doi. org/10.11603/2415-8798.2017.4.8404. (in Ukrainian).

11. Shevchenko 0.S. Koinfektsiia tuberkuloz/VIL: epidemiolohichni pokaznyky v Kharkivskii oblasti za 2014 rik [Co-infection of TB/HIV: epidemiological indicators in the Kharkov region 2014 year]. Tuberkuloz, lehenevi khvoroby, VIL-infektsiia - Tuberculosis, Pulmonary Diseases, HIV Infection. 2015; 3: 89-91. (in Ukrainian).

12. Zozulia I.S, Zozulia A.I, Volosovets A.O. Nevrolohichni uskladnennia SNIDu [Neurological complications of AIDS]. Mizhnarodnyi nevrolohichnyi zhurnal - International neurological journal. 2019; 2 (104): 25-29. doi: https://doi.org/10.22141/2224-0713.2.104.2019.161632. (in Ukrainian).

13. Diachenko A. G., Efremin R. S., Grabovy S.L. et al. Ko-ynfektsyia vyrusov ymmunodefytsyta cheloveka y hepatyta C. Smena paradyhmy? [Coinfection of human immunodeficiency viruses and hepatitis C. Changing the paradigm?] Tuberkuloz, lehenevi khvoroby, VlL-infektsiia - Tuberculosis, Pulmonary Diseases, HIV Infection. 2017; 1:84-89. (in Russian).

14. Kim Y. J., Woo J. H., Kim M. J. et al. Opportunistic diseases among HIVinfected patients: a multicenter-nationwide Korean HIV/AIDS cohort study, 2006 to 2013. Korean J Intern Med. 2016; 31(5): 953-960. doi: $10.3904 / \mathrm{kjim} .2014 .322$.

15. Ilenko N. V., Petrushenko T. O., Ilenko N. M. Kilkisna otsinka populiatsii, subpopuliatsii limfotsytiv i fahotsytuiuchykh klityn u vil-infikovanykh patsiientiv [Quantitative assessment of populations, subpopulations of lymphocytes and phagocytic cells in HIV-infected patients] Ukrainskyi stomatolohichnyi almanakh - Ukrainian Dental Almanac. 2016; 1: 37-42. (in Ukrainian).

16. McArthur J. C., Brew B. J., Nath, A. Neurological complications of HIV infection. The Lancet Neurology. 2005; 4(9): 543-55. doi.org/10.1016/ S1474-4422(05)70165-4.

The work was performed within the framework of: research work of the Department of Infectious Diseases with Epidemiology of Sumy State University (SSU) "Common Infectious Diseases of the Northern Region of Ukraine: Modern Approaches to Diagnosis and Treatment" (state registration number 0117U003216) (deadline: 2017-2022). 


\section{ORCID and contributionship:}

Oksana M. Chemych: 0000-0003-1332-2175 A, B, C, D, E, F

Mykola D. Chemych: 0000-0002-7085-5448 A, B, C, D, E, F

Anna A. Olefir: 0000-0003-2692-6680 A,B, C, D

Oleh B. Berest: 0000-0003-0183-9871 A, B, C, F

\section{Conflict of interest:}

The Authors declare no conflict of interest.

\section{CORRESPONDING AUTHOR}

Oksana M. Chemych

Sumy state university

2 Rimsky-Korsakov St., 40000 Sumy, Ukraine

tel: +380664764966

e-mail: chemychoksana@gmail.com

Received:21.12.2020

Accepted: 01.04.2021

A - Work concept and design, B - Data collection and analysis, C - Responsibility for statistical analysis,

D-Writing the article, $\mathbf{E}$-Critical review, $\mathbf{F}$ - Final approval of the article 